\title{
Metabolic Changes in Phenolic Compounds in Buds during and after Dormancy Releasing in Early and Late (Malus sylvestris, Mill) Apple Varieties as Effected by Chilling Requirements
}

\author{
Mohamed A. Seif El-Yazal \\ Botany Department, Faculty of Agriculture, Fayoum University, Fayoum 63514, Egypt \\ Corresponding author e.mail: mas04@fayoum.edu.eg
}

Keywords: Apple, Chilling requirements, Dormancy, Phenolic compounds

\begin{abstract}
In order to study the relation between seasonal changes in phenolic compounds and flower opining date according to chilling requirements. Variations in chilling requirements, bud burst and development in early and late- opining apple varieties, Barkhar, Local and Strakhan (Malus sylvestris) were investigated. Results showed less bud burst in late varieties than in early ones. In the former, there were increase in phenolic compounds (conjugated and total phenols) at budburst in all varieties. As dormancy free phenols increased, coinciding with a reduction in the levels of conjugated phenols. Consequently, as dormancy breaks, these free phenols conjugates with organic constituents, and a decrease in the concentrations of free phenols occurs, in order to reduce inhibitory effect on growth. We conclude that late varieties (Strakhan) are less economical in manufacturing new growth, as indicated by less bud vigor at budburst than early varieties (Barkhar and local) and show a marked differential phenols compound pattern throughout bud development compared to early varieties.
\end{abstract}

\section{Introduction}

Dormancy in deciduous fruit trees is a physiological syndrome occurring annually to enable plants to survive cold winters. Deciduous trees require exposure to low winter temperatures is called a chilling requirement to overcome dormancy and grow in the following spring (Howe et al., 1999 and Arora et al., 2003). Also, Njuguna et al. (2004) reported that, temperate zone fruit crops undergo bud dormancy which can be described as a mechanism for avoiding the exposure of tender flowers and leaves to low winter temperatures. The induction of dormancy occurs in response to seasonal environmental signals. In most woody plants, shortening of the photoperiod induces growth cessation, bud set, and in some degree, cold acclimatization. The subsequent drop in temperature then leads to a greater tolerance to cold and leaf fall (Allona et al., 2010).

The relationship between plant phenols and bud dormancy as well as bud break was studied by several workers (Morsi and El-Yazal, 2008 and Zahra et al., 2009). Plant phenol may be divided into three groups, promotive, inhibitive and inactive. Promotion of plant growth by phenols may proceed through the modulation of either IAA biosynthesis or its destruction (Kefeli and Kutacek, 1977). Also, Sagi and Garay (1961) reported that phenolic effect on plant growth was contributed to the antagonism with indole acetic acids activity. Higher amounts of phenolic substances were found in dormant buds, but lower amounts were found after bud release from dormancy, then phenols increased until the start of bud expansion (Wang et al., 1991). The reduction in free phenols may be attributed to conjugation with other molecules which increases the endogenous promoters and reduction of endogenous inhibitors in buds that led to an increase in plant growth parameters. The incidence, termination, regulation and management of dormancy were regulated by seasonal changing in phenolic compound. (Seif El-Yazal and Rady, 2014). The majority of trees in temperate climates fulfill a chilling requirement (CR) so as to overcome endodormancy (Campoy et al. 2012). Therefore, the CR could variation by species, varieties, or growing regions (Stino, 1995, Luedeling and Brown, 2011, Wang et al., 2012, Andreini et al., 2012). Cultivars with low CR bloom and ripen earlier, whereas those with high CR bloom and ripen later (Scorza and Okie, 1990). CR constrains the acceptable areas of cultivation of the various commercially important tree 
species and cultivars around the world. If chilling requirement don't appear to be met, irregular, delayed and asynchronous growth, flowering and fruit set are located inside the subsequent season (Luedeling et al., 2009, Campoy et al., 2011).

Additionally, this research may help further studies to be performed on how chilling requirement affect changes in the length to full bud break, plant regulators and help to express the effect of phenolic compounds on flowering and yield

\section{Materials and Methods}

Thirteen year-old trees of 'Barkhar, local and Strakhan' apple trees (Malus sylvestris Mill.) grafted on Malling-Merton 106 (MM 106) rootstock were designated willy-nilly, for a preliminary study in 2016/2017, 2017/2018 and 2018/2019 seasons. All trees were full-grown within the wood let (newly reclaimed saline chalky soil) of the Horticultural Station at Aboksah in Abshawai, Fayoum, Egypt. For the most 2-seasons study, designated trees of every selection $(\mathrm{n}=6)$ were tagged in November 2016 and 2017, and sampled from September-March 2017/2018 and 2018/ 2019. Trees chosen for the study within the 1 st season were not the identical trees that were designated for the second season. Every tree was designed together replicate, and every selection enclosed six trees (total $\mathrm{n}=18$ )

\section{Quantification of chilling requirements}

In this study, from Nov to March, apple branches from every variety were collected each fifteen days and cultivated in artificial lighting setup with water to see the bud dormancy emotional time (50\% bud break). Moreover, the quantity of chilling hours (temperatures between 0 and $7.2{ }^{\circ} \mathrm{C}$ ) throughout this period till the time of gap buds in every variety was calculated (by using Thermograph). The foremost common chilling model, and one that is used wide, is that the Chilling Hours Model, additionally referred to as the Weinberger Model (Bennett 1949, Weinberger 1950). This model, that was $1^{\text {st }}$ developed for peaches in Georgia (United States), interprets all hours with temperatures between 0 and $7.2^{\circ} \mathrm{C}$ as effective for chilling accumulation. These chilling hours are accumulated through the winter season. Chilling hour's below $7.2^{\circ} \mathrm{C}$ from $1^{\text {st }}$ November to every opining date in three apple varieties under study in 2017/2018 and 2018/2019 seasons were determined (Table 1).

\section{Morphological characteristics and yield measurements on trees}

Bud count was created for every tree $(n=6)$ in each variety. The dates that floral and vegetative buds began to open were recorded. Additionally, the dates that flowering reached 25, 50, 75 and $100 \%$ of the full flowers were calculated in each variety. The dormant buds were additionally counted and were expressed, with opened buds, as a proportion of the full number of buds. The ultimate fruit set was calculated 6 weeks after full bloom stage as a variety of persisted fruits per hundred spur and lateral buds (Westwood, 1978). At harvest stage, apple fruits were harvested, counted and weighed for every examined tree.

\section{Preparation of bud samples for chemical analyses.}

Bud samples were collected at 15-day intervals beginning from $1^{\text {st }}$ September up to $15^{\text {th }}$ March from each replicate of each treatment to determine the seasonal changes in bud contents from free, conjugated and total phenols. Samples of vegetative and floral buds were randomly taken and immediately transported to the laboratory for the aforementioned determinations.

Estimation of free, conjugated and total phenolics content in apple buds using Folin-Ciocalteu Reagent

Free and total phenols in buds were determined as $\mathrm{mg} / \mathrm{g}$ fresh weight using folin-ciocalteu reagent and Sodium carbonate solution according to (Galicia et al., 2009) with some modification. Weigh a random sample of $(2 \mathrm{~g})$ buds without scales as a representative of the fresh material. Dry the buds at $64-65^{\circ} \mathrm{C}$ for 16 hours. Grind each sample to a very fine powder.

Extraction of Free phenols 
Weigh $100 \mathrm{mg}$ of each powder of samples in an eppendorf tube and add $6.5 \mathrm{ml}$ of methanol $(50 \%)$. Close the tubes and ensure no evaporation will take place during extraction. Vortex thoroughly the samples and place them in a thermo mixer at $65{ }^{\circ} \mathrm{C}$ with $900 \mathrm{rpm}$ for 30 minutes. Take the tubes out of the thermo mixer and let them to cooling at room temperature. Then, centrifuge the tubes at 14,000 rpm for 5 minutes and ensure the supernatant does not have sample particles floating in it; if it does, centrifuge again. Make the colorimetric reaction.

\section{Extraction of Total phenols}

For each sample, weigh $100 \mathrm{mg}$ of powder in an eppendorf and add $6.5 \mathrm{ml}$ of hydrochloric acid in methanol $(10 \mathrm{ml}$ of $\mathrm{HCl} 1.2 \mathrm{M}$ with $90 \mathrm{ml}$ methanol). Close the tubes and ensure no evaporation will take place during extraction. Vortex thoroughly the samples and place them in a thermomixer at $42{ }^{\circ} \mathrm{C}$ and $1100 \mathrm{rpm}$ for 30 minutes. Take the tubes out of the thermomixer and let them cool at room temperature. Centrifuge the tubes at $14,000 \mathrm{rpm}$ for 5 minutes. Ensure that the supernatant does not have sample particles floating in it; if it does, centrifuge again. Take $2.5 \mathrm{~mL}$ of supernatant, put it in new eppendorf. Reduce to dryness and resuspend the precipitate resulting in $6.5 \mathrm{ml}$ of methanol. Vortex thoroughly and make the colorimetric reaction.

\section{Colorimetric Reaction}

Take $1 \mathrm{~mL}$ of supernatant and carefully transfer into test tube. Then, add $0.8 \mathrm{~mL}$ of $5 \%$ Folin-Ciocalteu reagent (dissolve $10 \mathrm{~g}$ sodium tungstate and $2.5 \mathrm{~g}$ sodium molybdate in $70 \mathrm{ml}$

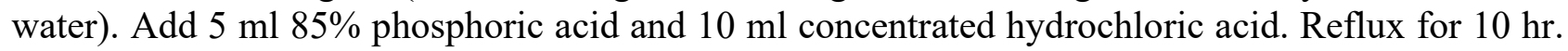
Add $15 \mathrm{~g}$ lithium sulfate, $5 \mathrm{ml}$ water and 1 drop bromine. Reflux for $15 \mathrm{~min}$. Cool to room temperature and bring to $100 \mathrm{ml}$ with water. Then take $2.5 \mathrm{ml}$ of F-C $2 \mathrm{~N}$ with $7.5 \mathrm{ml}$ of deionized water and vortex thoroughly). The F-C reagent should be added before the alkali to avoid the airoxidation of phenolics. Add $2.2 \mathrm{~mL}$ of $400 \mathrm{mM} \mathrm{Na}_{2} \mathrm{CO}_{3}$ (4.25 g of $\mathrm{Na}_{2} \mathrm{CO}_{3}$ (99.9\%) in $100 \mathrm{ml}$ of deionized water). Cover the tubes with adhesive aluminum tape to avoid dropping of samples. Vortex the tubes at $800 \mathrm{rpm}$ for $10 \mathrm{sec}$. Incubate tubes at $42{ }^{\circ} \mathrm{C}$ for 9 minutes for color development. Take the tubes out of the oven and let them cool at room temperature, protect them from direct light. Read absorbance at $765 \mathrm{~nm}$ in a spectrophotometer. These estimates represented total phenols (conjugated and free phenols), free phenols and thus conjugated compounds were obtained by subtraction free phenols from total phenols.

\section{Statistical analysis}

The values of the determined characters were subjected to statistical analysis according to the standard procedure described in (Gomez and Gomez, 1984). The ' $F$ ' test was applied to assess the significance of the treatment at $5 \%$ level of probability

The values presented in the results obtained in this investigation are the mean of the two seasons under the study.

\section{Results}

\section{Impact of winter Chilling Hours on bloom date}

To confirm however the winter accumulated chilling hours affected the spring events; we tend to investigate the total bloom date ( $50 \%$ bud break) once completely different numbers of controlled chilling hours. Data in Table (1) show that the dormancy releasing time of Barkhar, Local and Strakhan varieties were $1^{\text {st }}$ of February, $1^{\text {st }}$ March and $27^{\text {th }}$ March, after the accumulation of 249, 280 and $285(\mathrm{CH})$ respectively in the first season and were $25^{\text {th }}$ of January, $15^{\text {th }}$ February and $20^{\text {th }}$ March, after the accumulation of 251,278 and $281(\mathrm{CH})$ respectively in the second season. There were about 27, 26 and 55 days difference in the first season, i.e., the occurrence of opening buds of Strakhan was 26 days later than that of Local and 55 days later than that of Barkhar in the first season and 20,32 and 53 days difference in the second season and also the occurrence of opening buds of Strakhan was later than that of Local 32 days later and 53 days later than that of Barkhar in the second season, indicating that the chilling hours of Strakhan was higher than that of 
Local and Barkhar varieties. Strakhan varity needed more of chilling hours accumulative at low temperature $\left(7.2^{\circ} \mathrm{C}\right)$ than Barkhar and Local for bud break. Moreover, the sum accumulative low temperature (chilling hours) of bud break were step by step happy within the two varieties, Barkhar and Local opened in Janurary, February and initial of March thanks to meeting the necessity of expeditiously accumulative low temperature $\left(\mathrm{CH} 7.2^{\circ} \mathrm{C}\right)$, whereas Strakhan still couldn't opened as a result of the expeditiously accumulative low temperature was but required for bud break $\left(\mathrm{CH} 7.2^{\circ} \mathrm{C}\right)$.

Table 1. Chilling accumulation (hours below $7.2^{\circ} \mathrm{C}$ ) from $1^{\text {st }}$ November to each break date for each variety during 2017/2018 and 2018/2019.

\begin{tabular}{|l|l|l|l|l|}
\hline \multirow{2}{*}{ Varietes } & \multicolumn{3}{|c|}{ Hours under temperature $7.2^{\circ} \mathrm{C}$ from $1^{\text {st }}$ November to 50\% bud break } \\
\cline { 2 - 5 } & \multicolumn{3}{|c|}{$2016 / 2017$} & \multicolumn{2}{c|}{$2018 / 2019$} \\
\cline { 2 - 5 } & $\begin{array}{l}\text { Date of 50\% bud } \\
\text { break }\end{array}$ & $\begin{array}{l}\text { Chilling } \\
\text { Hours }\end{array}$ & $\begin{array}{l}\text { Date of 50\% bud } \\
\text { break }\end{array}$ & Chilling horse \\
\hline Barkhar & $1^{\text {st }}$ February & 249 & $25^{\text {th }}$ January & 251 \\
\hline Local & $1^{\text {st }}$ March & 280 & $15^{\text {th }}$ February & 278 \\
\hline Strakhan & $27^{\text {th }}$ March & 285 & $20^{\text {th }}$ March & 281 \\
\hline
\end{tabular}

\section{Date of floral bud break}

With the buildup of low temperature, the chilling demand for fruit trees was step by step happy. Data in Table (2) indicated the dates to flowering (50\% flowering) 14 February, 17 March and 12 April for Barkhar, Local and Strakhan, respectively. The earliness reached about 57 and 26 days for Barkhar and Local apple varieties respectively as comparison with Strakhan variety.

Table 2. Date of flower bud opening and flowering period in apple varieties.

\begin{tabular}{|c|c|c|c|c|c|c|}
\hline \multirow[b]{2}{*}{ Varieties } & \multicolumn{6}{|c|}{ Date of flower bud opening } \\
\hline & Beginning & $\begin{array}{l}25 \% \\
\text { flowering }\end{array}$ & $\begin{array}{l}50 \% \\
\text { flowering }\end{array}$ & $\begin{array}{l}75 \% \\
\text { flowering }\end{array}$ & $\begin{array}{l}\text { End of } \\
\text { flowering }\end{array}$ & $\begin{array}{l}\text { Flowering } \\
\text { period } \\
\text { (day) }\end{array}$ \\
\hline Barkhar & $11^{\text {st }}$ February & $12^{\text {st }}$ February & $14^{\text {st }}$ February & $16^{\text {th }}$ February & $22^{\text {th }}$ February & 12 \\
\hline Local & $4^{\text {st }}$ March & $13^{\mathrm{st}} \mathrm{March}$ & $17^{\text {th }}$ March & $20^{\text {th }} \mathrm{March}$ & $21^{\text {th }}$ March & 18 \\
\hline Strakhan & $7^{\text {st }}$ April & $10^{\text {st }}$ April & $12^{\text {st }}$ April & $19^{\text {th }}$ April & $25^{\text {th }}$ April & 19 \\
\hline
\end{tabular}

\section{Proportion of bud break and fruit set}

Data presented in Table (3) indicated that early- opining apple varieties gave a high percentage of flower bud break and fruit set comparing with the late-opining apple variety. The proportion of flower bud break was 89.80 and $85.91 \%$ for Barkhar and Local apple varieties respectively as comparison with $76.16 \%$ for Strakhan variety. However, the percentage of fruit set was 55.50 and $39.01 \%$ for Barkhar and Local apple varieties respectively as comparison with $13.65 \%$ for Strakhan variety.

Table 3. Percentage of bud break, dormant buds and fruit set in three apple varieties.

\begin{tabular}{|l|c|c|c|}
\hline Varieties & Bud break (\%) & Dormant buds (\%) & Fruit set (\%) \\
\hline Barkhar & $89.80 \mathrm{a}$ & $10.20 \mathrm{a}$ & $55.50 \mathrm{a}$ \\
Local & $85.91 \mathrm{~b}$ & $14.09 \mathrm{~b}$ & $39.01 \mathrm{~b}$ \\
Strakhan & $76.16 \mathrm{c}$ & $23.84 \mathrm{c}$ & $13.65 \mathrm{c}$ \\
\hline
\end{tabular}

Mean pairs followed by different letters are significantly different $(p=0.05)$ by Duncan's test; $n=6$

\section{Number of fruit tree ${ }^{-1}$ and Fruit yield}

Data in Table (4) also show that, early-flower opining apple varieties have great number of apple fruits tree ${ }^{-1}$ and total fruit yield tre $\mathrm{e}^{-1}$ when compared to the late- opining apple variety. It exceeded by 94.39 and $59.72 \%$ for number of fruits tree ${ }^{-1}$ and 61.43 and $22.37 \%$ for fruit yield tree $^{-1}$ in the Barkhar and Local apple varieties respectively as comparison with Strakhan variety. 
Table 4. Number of fruit tree ${ }^{-1}$ and yield per tree $(\mathrm{kg})$ in three apple varieties.

\begin{tabular}{|l|c|c|}
\hline Varieties & No. of Fruit tree ${ }^{-1}$ & Yield per tree $(\mathrm{Kg})$ \\
\hline Barkhar & $432.20 \mathrm{a}$ & $23.02 \mathrm{a}$ \\
\hline Local & $355.12 \mathrm{~b}$ & $17.45 \mathrm{~b}$ \\
\hline Strakhan & $222.33 \mathrm{c}$ & $14.26 \mathrm{c}$ \\
\hline
\end{tabular}

Mean pairs followed by different letters are significantly different $(p=0.05)$ by Duncan's test; $n=6$

\section{Total soluble phenols}

Data in Table (5) indicated that the total soluble phenols in vegetative buds gradually decreased from the first sample reaching its minimum value at $15^{\text {th }}$ of December in Barkhar variety, while in both Strakhan and Local varieties, total soluble phenols increased from the first sample till $1^{\text {st }}$ and $15^{\text {th }}$ October followed with a marked decrease reaching its minimum amount on the $15^{\text {th }}$ of December in Local and till $1^{\text {st }}$ of January in Strakhan variety. Thereafter, the amount of total soluble phenols increased sharply towards the last sample in all the studied varieties.

As regards to total soluble phenols of the flower buds, data show that it increased slightly till $15^{\text {th }}$ of September in Barkhar and $1^{\text {st }}$ October in both Strakhan and Local varieties then decreased sharply reaching its minimum amount at $1^{\text {st }}$ of December for Barkhar and Local varieties and on $15^{\text {th }}$ of December for Strakhan variety. Thereafter, the amount of total soluble phenols increased markedly towards the last sample in all the studied varieties.

Table 5. Seasonal changes in total phenols (mg./g. D.W.) in buds of the three apple varieties during and after release from dormancy.

\begin{tabular}{|l|l|l|l|l|l|l|}
\hline \multirow{2}{*}{ Dates } & \multicolumn{5}{|c|}{ Varieties } \\
\cline { 2 - 7 } & \multicolumn{2}{|c|}{ "Barkhar" } & \multicolumn{2}{c|}{ "Local" } & \multicolumn{2}{c|}{ "Strakhan" } \\
\cline { 2 - 7 } & V. & \multicolumn{1}{|c|}{ F. } & V. & F. & V. & F. \\
\hline $1 / 9$ & 74.43 & 64.10 & 62.05 & 62.22 & 65.55 & 60.61 \\
\hline $15 / 9$ & 74.03 & 64.36 & 64.52 & 67.87 & 68.04 & 64.65 \\
\hline $1 / 10$ & 71.08 & 47.18 & 67.57 & 73.09 & 73.18 & 74.18 \\
\hline $15 / 10$ & 67.63 & 43.76 & 76.71 & 56.29 & 70.01 & 67.89 \\
\hline $1 / 11$ & 63.71 & 41.93 & 71.11 & 48.31 & 67.95 & 43.44 \\
\hline $15 / 11$ & 48.11 & 34.68 & 43.72 & 35.75 & 67.86 & 39.09 \\
\hline $1 / 12$ & 47.41 & 25.05 & 43.65 & 34.22 & 62.45 & 36.33 \\
\hline $15 / 12$ & 45.30 & 36.29 & 39.25 & 42.35 & 53.89 & 33.13 \\
\hline $1 / 1$ & 49.39 & 36.79 & 51.05 & 42.74 & 38.60 & 34.60 \\
\hline $15 / 1$ & 60.41 & 43.16 & 54.04 & 64.16 & 40.51 & 44.28 \\
\hline $1 / 2$ & 77.30 & 65.07 & 59.12 & 71.37 & 71.39 & 44.60 \\
\hline $15 / 2$ & 84.08 & 65.71 & 60.90 & 71.07 & 75.47 & 45.19 \\
\hline $1 / 3$ & ------ & ------ & 74.07 & ------ & 78.33 & 47.46 \\
\hline $15 / 3$ & ------ & ------ & 74.26 & ------ & 78.63 & 48.02 \\
\hline
\end{tabular}

$\mathrm{V} .=$ Vegetative buds

F. $=$ Flower buds

\section{Free phenols}

Data in Table (6) recorded that the amount of free phenols in vegetative buds of the three studied varieties generally increased from the first sample reaching its maximum at $15^{\text {th }}$ of November in both Local and Strakhan varieties and till $1^{\text {st }}$ of December in Barkhar variety, although a marked decrease occurred on the $15^{\text {th }}$ of October for Local and Strakhan and $15^{\text {th }}$ of November in Barkhar variety. Thereafter, the amount of free phenols tended to decrease towards the last sample in all varieties. As regards to the free phenols of the flower buds, data show that it increased 
gradually from the first sample reaching its maximum value on the 1st December in both Barkhar and Strakhan varieties and $15^{\text {th }}$ of December in Local variety with some fluctuation. Thereafter, the amount of free phenols tended to decrease towards the last sample in all varieties.

Table 6. Seasonal changes in free phenols (mg./g. D.W.) in buds of the three apple varieties during and after release from dormancy.

\begin{tabular}{|l|l|l|l|l|l|l|}
\hline \multirow{2}{*}{ Dates } & \multicolumn{5}{|c|}{ Varieties } \\
\cline { 2 - 7 } & \multicolumn{2}{|c|}{ "Barkhar" } & \multicolumn{2}{c|}{ "Local" } & \multicolumn{2}{c|}{ "Strakhan" } \\
\cline { 2 - 7 } & \multicolumn{1}{|c}{ V. } & \multicolumn{1}{c|}{ F. } & \multicolumn{1}{c|}{ V. } & F. & V. & F. \\
\hline $1 / 9$ & 24.53 & 18.02 & 25.00 & 15.84 & 18.73 & 18.20 \\
\hline $15 / 9$ & 24.84 & 19.35 & 25.20 & 18.84 & 19.26 & 19.86 \\
\hline $1 / 10$ & 25.99 & 18.02 & 25.36 & 18.76 & 22.43 & 21.88 \\
\hline $15 / 10$ & 24.20 & 17.38 & 22.67 & 15.11 & 21.23 & 19.92 \\
\hline $1 / 11$ & 22.71 & 15.86 & 22.86 & 16.40 & 2163 & 23.16 \\
\hline $15 / 11$ & 21.58 & 19.35 & 28.03 & 17.04 & 28.41 & 23.27 \\
\hline $1 / 12$ & 26.63 & 19.59 & 22.71 & 22.96 & 26.99 & 23.49 \\
\hline $15 / 12$ & 26.05 & 18.35 & 17.21 & 24.87 & 24.35 & 12.35 \\
\hline $1 / 1$ & 19.48 & 13.91 & 15.60 & 18.54 & 17.61 & 9.77 \\
\hline $15 / 1$ & 15.72 & 12.48 & 15.57 & 17.49 & 17.69 & 9.67 \\
\hline $1 / 2$ & 14.30 & 8.57 & 15.36 & 16.69 & 16.38 & 9.02 \\
\hline $15 / 2$ & 13.94 & 7.61 & 14.04 & 15.89 & 16.89 & 8.37 \\
\hline $1 / 3$ & ------ & ---- & 14.04 & ----- & 12.92 & 8.10 \\
\hline $15 / 3$ & ------ & ---- & 14.01 & ------ & 12.52 & 8.01 \\
\hline
\end{tabular}

$\mathrm{V} .=$ Vegetative buds

F. $=$ Flower buds

\section{Conjugated phenols}

Conjugated phenols were found in the vegetative and flower buds at different intervals during the considered seasons are presented in Table (7). It can be generally noticed that conjugated phenols found in vegetative buds of Barkhar variety gradually decreased from the first sample reaching its minimum value at $15^{\text {th }}$ of December, while in Strakhan and Local varieties, conjugated phenols increased from the first sample till $1^{\text {st }}$ and 15 th October followed with a marked decrease reaching its minimum amount on the $15^{\text {th }}$ of November in Local and till $1^{\text {st }}$ of January in Strakhan variety. Thereafter, the amount of conjugated phenols increased sharply towards the last sample in all the studied varieties.

As regards to conjugate phenols of the flower buds, data show that it increased slightly in both Strakhan and Local varieties till the third sample then decreased sharply reaching its minimum amount at $1^{\text {st }}$ of December for all varieties. Thereafter, the amount of conjugated phenols increased markedly towards the last sample in all the studied varieties. 
Table 7. Seasonal changes in conjugated phenols (mg./g. D.W.) in buds of the three apple varieties during and after release from dormancy.

\begin{tabular}{|l|l|l|l|l|l|l|}
\hline \multirow{2}{*}{ Dates } & \multicolumn{3}{|c|}{ Varieties } \\
\cline { 2 - 7 } & \multicolumn{2}{|c|}{ "Barkhar" } & \multicolumn{2}{c|}{ "Local" } & \multicolumn{2}{c|}{ "Strakhan" } \\
\cline { 2 - 7 } & V. & \multicolumn{1}{|c|}{ F. } & \multicolumn{1}{c|}{ V. } & F. & V. & F. \\
\hline $1 / 9$ & 49.90 & 46.08 & 37.05 & 46.38 & 46.82 & 42.41 \\
\hline $15 / 9$ & 49.19 & 45.01 & 39.32 & 49.03 & 48.78 & 44.79 \\
\hline $1 / 10$ & 45.09 & 29.16 & 42.21 & 53.33 & 50.75 & 52.30 \\
\hline $15 / 10$ & 43.43 & 26.38 & 54.04 & 41.18 & 48.78 & 47.97 \\
\hline $1 / 11$ & 41.00 & 26.07 & 48.25 & 31.91 & 46.32 & 20.28 \\
\hline $15 / 11$ & 26.53 & 15.33 & 15.69 & 18.71 & 39.45 & 15.82 \\
\hline $1 / 12$ & 20.78 & 15.46 & 20.94 & 11.26 & 35.46 & 12.84 \\
\hline $15 / 12$ & 19.25 & 17.94 & 22.04 & 17.48 & 29.99 & 20.78 \\
\hline $1 / 1$ & 29.91 & 22.88 & 35.45 & 24.20 & 20.99 & 24.83 \\
\hline $15 / 1$ & 44.69 & 30.68 & 38.47 & 46.67 & 29.82 & 34.61 \\
\hline $1 / 2$ & 63.50 & 56.87 & 43.76 & 54.68 & 55.01 & 35.58 \\
\hline $15 / 2$ & 70.14 & 58.10 & 46.86 & 55.18 & 58.52 & 36.82 \\
\hline $1 / 3$ & ------- & ------ & 60.03 & ------ & 65.41 & 39.36 \\
\hline $15 / 3$ & ------- & ------- & 60.25 & ------ & 66.11 & 40.01 \\
\hline
\end{tabular}

$\mathrm{V} .=$ Vegetative buds

F.=Flower buds

\section{Discussion}

It is clear nowadays that a wide variety of factors can break dormancy, in particularly environmental and phenols influences have to be analyzed to understand the complex mechanism which start when the bud resume growth. During the process of the release of buds from dormancy, many changes in some chemical components in vegetative and floral buds, particularly the contents of endogenous phenols (total, free and conjugated phenols) (Table 5, 6 and 7) play a vital role in regulating dormancy and bud break. The most of phenol compounds have been isolated from bud scales and have growth inhibitor role in buds. Literature reported by researchers and our works indicate that phenol compounds increased during rest in flower buds, then decreased after rest and completely eliminated at blooming (Seif El-Yazal and Seif El-Yazal, 2013). The chilling period influences during disappear them. Therefore, the previous studies were undertaken to determine if such a relationship exists between bud break and the phenol contents or not (Jindal and Mankotia, 2004). The increasing in bud break may be due to the reduction in free phenols (endogenous inhibiters) which contrasted with the increase in endogenous promoters i.e. total indoles and consequently endogenous inhibitors decreased in the buds which led to increasing in plant growth parameters (Seif El-Yazal et al., 2014 and 2018). In this respect, Sagi and Garay (1961) showed that phenolic effect on plant growth was contributed to either antagonism with IAA activity. Moreover, Zenk and Muller (1963) suggested that phenols exerted their effect through an IAA carboxylation reaction. Also, Kefeli and Kutacek (1977) suggested that the inhibition of plant growth by the plant phenols may be effective in one of the following ways (1) depression of IAA biosynthesis and /or activation of IAA degradation; (2) lowering of growth stimulating activity of IAA, gibberellins or cytokinins; (3) uncoupling of respiration and oxidative phosphorylation and (4) interaction of quinine forms of phenols with proteins and hence inhibition of metabolic pathways. Moreover, Codignola et al. (1988a) reported that, phenol compositions has been increased from November to February and then, have been decreased in March and have been eliminated on blooming stage in 
peach buds. Several studies have shown correlation between bud break and seasonal variation of phenols in trees (Codignola et al., 1988b). The evaluation of dormant buds has shown that, phenol compounds rarely occur in a free state within the cell; rather they are commonly conjugated with other molecules. This finding could be taken some evidence, that, phenols could be play important role to protection buds during winter, dormant season and bud break. In this respect, Kefeli and Kutacek (1977) suggested that plant phenol may be decided into three groups; promotive, inhibitor and inactive. They added that promotion of plant growth by phenols may proceed through the modulation of either IAA biosynthesis or its destruction. Moreover, Wang et al. (1991) on apple found that dormant buds contained a high amount of phenolic substances which decreased after bud break then increased until the start of bud expansion. Phenolic compounds are found to be patent modifiers of catalase, peroxidase and polyphenol oxidase activity, as both inhibitors and stimulators in apple buds. Moreover, these substances may be stimulated the oxidation process of phenols by increasing the peroxidase activity.

\section{Conclusion}

The hypothesis tested by this study was that the content of phenolic compounds such as conjugated and total phenols in apple trees increases and free phenols decrease prior to the buds sprouting during winter and spring in the region of Egypt. Therefore, the objective was to determine the phenolic compounds in early and late varieties of apple trees (Barkhar, Local and Strakhan) during and after dormancy. Finally, from the results of the current investigation, it may well be all over that, phenolic compounds (conjugated and total phenols) were exaggerated from dormancy initiation to dormancy release that slashed throughout deep dormancy and increased with bud break. In contrast, free phenols were decreased from dormancy initiation to dormancy release that increased throughout deep dormancy and decreased with bud break.

\section{References}

[1] Allona, I., Ramos, A., Ibáñez, C., Contreras, A., Casado, R., Aragoncillo, C., (2010). Review: molecular control of winter dormancy establishment in trees. Spanish Journal of Agricultural Research 6, 201-210.

[2] Andreini, L., Viti, R., Bartolini, S., Ruiz, D., Egea, J., Campoy, J.A. (2012).The relationship between xylem differentiation and dormancy evolution in apricot flower buds (Prunus armeniaca L.): the influence of environmental conditions in two Mediterranean areas. Trees, 26, 919-928.

[3] Arora, R., Rowland, L.J., Tanino, K. (2003). Induction and release of bud dormancy in woody perennials: a science comes of age. Hort.Science 38, 911-921.

[4] Bennett, J.P. (1949). Temperature and bud rest period. Calif. Agric., 3 (11), 9-12.

[5] Campoy, J.A., Ruiz, D., Egea, J. (2011). Dormancy in temperate fruit trees in a global warming context: a review. Sci Hortic., 130(2), 357-372. doi: 10.1016/j.scienta.2011.07.011. [CrossRef]

[6] Campoy, J. A., Ruiz, D., Allderman, L., Cook, N., Egea, J. (2012). The fulfillment of chilling requirements and the adaptation of apricot (Prunus armeniaca L.) in warm winter climates: An approach in Murcia (Spain) and the Western Cape (South Africa). European Journal of Agronomy, 37, 43-55.

[7] Codignola, A., Maffel, M., Fieschi, M. (1988a). Phenols and bud dormancy. New Phytol 110, 473-477.

[8] Codignola, A., Maffel, M., Fieschi, M. (1988b). Phenols and bud dormancy, qualitative variation in endogenous phenols in dormant buds of Fagus sylvatica L. New Phytol 108, 473477. 
[9] Galicia, L., Nurit, E., Rosales, A., Palacios-Rojas, A. (2009). Laboratory Protocols: Maize Nutrition Quality and Plant Tissue Analysis Laboratory. CIMMYT, Mexico, DF

[10] Gomez, K.A., Gomez, A.A. (1984). Statistical Analysis Procedure of Agricultural esearch. John Wiley and Sons, New York, pp. 25-30.

[11] Howe, G. T., Davis, J., Jeknic, Z., Chen, T. H. H., Barbara Frewen, Bradshaw, H. D., Saruul, P. (1999). Physiological and genetic approaches to studying endodormancy-related traits in populus. Hort. Science 34, 1174-1184.

[12] Jindal, K.K., Mankotia, M.S. (2004). Impact of changing climatic conditions on chilling units, physiological attributes and productivity of apple in western himalagas. Acta Hort 662, 111117.

[13] Kefeli V, Kutacek M (1977). Phenolic substances and their possible role in plant growth regulation. Plant Growth Regul., 5, 472.

[14] Luedeling, E., Blanke, M., Gebauer, J. (2009). Climate change effects on winter chill for fruit crops in Germany-Auswirkungen des Klimawandels auf die Verfügbarkeit von Kältewirkung (Chilling) für Obstgehölze in Deutschland. Erwerbs-Obstbau., 51, 81-94. doi: 10.1007/s10341-009-0085-4. [CrossRef]

[15] Luedeling, E., Brown, P. H. (2011). A global analysis of the comparability of winter chill models for fruit and nut trees. International Journal of Biometeorology, 55, 411-421.

[16] Morsi, M.E., El-Yazal, M.A. (2008). Effect of garlic and onion extract on bud break, growth, yield, berry quality and some chemical constituents of flame seedless and superior grapevines (Vitis vinifera L.). Egypt J. Hort. 35, 1-28.

[17] Njuguna, J.K., Wamocho, L.S., Morelock, T.E. (2004). Temperate fuits production in the tropics: A Review on Apples in Kenya. Hort. Science 39 (4), 841-897.

[18] Sagi, F., Garay, A.S. (1961). The dependence of auction oxidase activity on the photoperiodically conditioned phenol content of the leaves and their age in Lupinus albus. Horticultural Abstracts 31, 3688.

[19] Scorza, R., Okie, W. R. (1990). Peaches (Prunus Persica L. Batsch). Acta Horticulturae, 290, $177-231$.

[20] Seif El-Yazal, M.A., Rady, M.M. (2014). Exogenous onion extract hastens bud break, positively alters enzyme activity, hormone, amino acids and phenol contents, and improves fruit quality in 'Anna' apple trees. Scientia Horticulturae, 169, 154-160.

[21] Seif El-Yazal, S.A., Seif El-Yazal, M.A. (2013). Causes of bud dormancy and the new methods for breaking it. LAP LAMBERT Academic Publishing. Deutscland/ Germany.

[22] Seif El-Yazal, M.A., Seif El-Yazal, S.A., Rady, M.M. (2014). Exogenous dormancy-breaking substances positively change endogenous phytohormones and amino acids during dormancy release in 'Anna' apple trees. Plant Growth Regul., 72, 211-220.

[23] Seif El-Yazal, M.A., Rady, M.M., Seif El-Yazal, S.A.(2018). Foliar-applied mineral oil enhanced hormones and phenols content and hastened breaking bud dormancy in "Astrachan" apple trees. International Journal for Empirical Education and Research, 1 (2), 57-73.

[24] Stino, G. R. (1995). Aspects related to temperature zone fruit production in Egypt. Acta Hort., 409, 203-204.

[25] Wang, S.F., Clark, C.J., Boldingh, H.L. (1991). Changes in the activities of catalase, peroxidase and polyphenol oxidase in apple buds during bud break induced by thidiazurin. J. Plant Growth Regulation, 10, 3-39. 
[26] Wang, L. R., Zhu, G. R., Fang, W. C. (2012). Peach genetic diversity, origin, and evolution. In: Wang L R, Zhu G R, Fang W C, eds., Peach Genetic Resource in China. Chinese Agriculture Press, Beijing, China. p. 263. (in Chinese)

[27] Weinberger, J.H. (1950). Chilling requirements of peach varieties. Proc Am Soc. Hortic. Sci., $56,122-128$.

[28] Westwood, M.N. (ed) (1978). Dormancy and plant hardiness. In: Temperate zone pomology. Freeman, San Francisco, pp 299-319.

[29] Zahra, P., Majid, R., Amin, B. (2009). Seasonal changes of peroxidase, polyphenol oxidase enzyme activity and phenol content during and after rest in pistachio (Pistacia vera L.) flower buds. World Appl. Sci. J., 6, 1193- 1199.

[30] Zenk, M.H., Muller, G.(1963). Distribution of exogenously applied indole-3-acetic acid as influenced by naturally occurring phenolic acid. Nature, 200, 761-763. 